\title{
Characteristics and first treatment dose of Dutch patients (12-60 years old) receiving prescriptions for asthma and initiating inhaled corticosteroids (ICS) therapy as either extra-fine (EF) ciclesonide or standard-particle (SP)-ICS
}

Daniela Van Eickles ${ }^{1 *}$, David Price ${ }^{2,3}$ Javaria Mona Khalid ${ }^{1}$, Ron Herings ${ }^{4}$, Jetty Overbeek ${ }^{4}$, Julie Von Ziegenweidt ${ }^{3}$, Muzammil Ali $^{3}$, Cristiana Miglio ${ }^{3}$

From 3rd WAO International Scientific Conference (WISC) 2014

Rio de Janeiro, Brazil. 6-9 December 2014

\section{Background}

Asthma management guidelines suggest little difference between EF and SP-ICS other than potency and therefore EF-ICS should be used at same dose as fluticasone (FP) and half the dose of SP-beclomethasone (BDP). Cohort studies suggest EF-BDP patients can achieve better asthma control than FP patients at lower doses. We compared baseline characteristics and first prescribed doses of patients initiating ciclesonide vs. SP-ICS.

\section{Methods}

Data from the PHARMO Database Network (pharmacy and hospital discharge records) on patients (12-60 years old) with $\geq 2$ prescriptions for asthma therapy (20052012) were compared over 1 year before initiating ciclesonide vs SP-ICS. Co-morbidities were evaluated over 1 year before and after ICS initiation. To avoid inclusion of potential COPD patients, those $>60$ years old and those using long-acting muscarinic antagonists were excluded. Sex and age at ICS initiation; initial ICS doses (actual prescribed doses); short-acting $\beta 2$-agonists (SABA) use (year before initiation); prescriptions for acute oral steroids and overall asthma control (no hospital admissions, no acute oral steroids and $\leq 200 \mathrm{mcg} /$ day salbutamol) in the year prior and including initiation date; and prescriptions of drugs for treating co-morbidities (year before and after initiation) were compared using t-test/chi-square test $(\mathrm{p}<0.05)$.

\section{Results}

Of 4,064 patients, 34\% initiated therapy as ciclesonide and $66 \%$ as SP-ICS, with same proportion of males (36\%). Differences $(\mathrm{p}<0.001$, unless otherwise specified) for ciclesonide vs. SP-ICS were: mean $( \pm$ SD) age $(43 \pm 13$ vs. $38 \pm 14$ years); median(Inter Quartile Range) initial ICS doses 160(160-160) vs. 500(250-500) $\mu$ g; proportion of patients not on SABA (72\% vs. $57 \%$ ) and on SABA daily dosage between $1-100 \mu \mathrm{g} /$ day ( $21 \%$ vs. $29 \%)$, 101 $200 \mu \mathrm{g} /$ day ( $5 \%$ vs. $9 \%$ ) and $>200 \mu \mathrm{g} /$ day ( $2 \%$ vs. $6 \%$ ); proportion of patients not prescribed acute oral steroids ( $90 \%$ vs. $88 \%, p=0.016)$ and with controlled asthma $(87 \%$ vs. $82 \%)$; proportion of patients prescribed nasal (44\% vs. $38 \%)$ and topical (31\% vs. $28 \%$ ) steroid preparations, proton-pump inhibitors ( $41 \%$ vs. $29 \%)$ and cardiac diseases or hypertension drugs ( $28 \%$ vs. $21 \%)$.

\section{Conclusions}

For comparable asthma control and similar prevalence of co-morbidities, patients were prescribed triple the dose of SP-ICS versus ciclesonide. Further to this analysis, the effects on asthma control in the year following ICS initiation will be investigated.

${ }^{1}$ Takeda International, UK

Full list of author information is available at the end of the article 


\section{Authors' details}

${ }^{1}$ Takeda International, UK. ${ }^{2}$ Academic Primary Care, University of Aberdeen, UK. ${ }^{3}$ Research in Real Life, UK. ${ }^{4}$ Pharmo Institute for Drug Outcomes Research, the Netherlands.

Published: 8 April 2015

doi:10.1186/1939-4551-8-S1-A259

Cite this article as: Van Eickles et al:: Characteristics and first treatment dose of Dutch patients (12-60 years old) receiving prescriptions for asthma and initiating inhaled corticosteroids (ICS) therapy as either extra-fine (EF) ciclesonide or standard-particle (SP)-ICS. World Allergy Organization Journal 2015 8(Suppl 1):A259.

Submit your next manuscript to BioMed Central and take full advantage of:

- Convenient online submission

- Thorough peer review

- No space constraints or color figure charges

- Immediate publication on acceptance

- Inclusion in PubMed, CAS, Scopus and Google Scholar

- Research which is freely available for redistribution

Submit your manuscript at www.biomedcentral.com/submit
C Biomed Central 